\title{
Inhalt.
}

Vorwort

Vorwort . . . . . . . . . . . . . . . . . . . . III

Literaturnachträge . . . . . . . . . . . . . . . . . . . . . . . . v

Abkürzungen ........................... . . . . . .

Die Klimazonen und -gebiete nach W. Köppen . . . . . . . . . vr

\section{Spezielle Wirtschaftageographie.}

I. Europa

Allgemeines ....................... 1

A. Nordeuropa (Schweden, Norvegen, Finnland) . . . . . . . . . 3

13. Westeuropa (Britische Inseln, Belgien mit Iuxemburg, Frankreich) Is

C. Südeuropa (Bulgarien, Gricchenland, Europäische Türkei, Albanien, Jugoslawien, Italien, Spanien, Portugal) . . . . . . . . . . 50

D. Südliches Mittelcuropa (Mittel-und Süddeutschland, Schweiz, Tschechoslowakei, Osterrcich, Ungarn, Rumänien) . . . . 81

Ii. Nürdliches Mitteleuropa (Niederlande, Dänemark, Norddeutschland, Frcie Stadt Danzig, Polen) . . . . . . . . . . . . 105

F. Ostouropa (Litauen, Lettland, Estland, Rußland) . . . . . . . 120

II. Asien 142

A. Vorderasien (Kleinasien, Transkaukasien, Armenien, Iran, Mesopotamien, Syrien, Palästina, Arabien) . . . . . . . . . 143

B. Hoch-oder Zentralasien (Ostturkestan, Dungarei, Mongolei, Tibet) 157

C. Nordwestasien (Turkestan und Westsibirien) . . . . . . . . 161

D. Nordostasien (Ostsibirien) . . . . . . . . . . . . . . 170

E. Ostasien (Amurland, Mandschurei, Korea, China, Japanische Inseln) 176

F. Südasien (Hinterindien, Vorderindien mit Ceylon, Austral-asiatischer Archipel) . . . . . . . . . . . . . . . . . 212

III. Australien und Ozeanien (australische Inselwelt)

Allgemeines . . . . . . . . . . . . . . . . . 263

A. Das Festland mit Tasmania (Commonwealth of Australia) . . . 264

B. Die australische Inselwelt (Ozeanien) . . . . . . . . . . 275

IV. Afrika

Allgemeines ..................... . 286

A. Die Atlasländer (Tunesien, Algerien, Marokko) . . . . . . . . 290

B. Das nordafrikanische Wüstengebiet (Ägypten, Libia usw.) . . 301

C. Nordwest-Nigritien (Oberguinea, West- und Mittelsudan) . . . . 312

D. Zentralafrika (Kongobecken und Umrandung) . . . . . . . 324 
Seite

E. Südafrika (bis zum Sambesi) . . . . . . . . . . . . . . . . 333

F. Ostafrika (mit dem Ostsudan und der Somalihalbinsel) . . . . 350

G. Die afrikanischen Inseln . . . . . . . . . . . . . . 360

V. Amerika

A. Germanisches Nordamerika, Allgemeines . . . . . . . . 374

1. Britisch-Nordamerika (Kanada und Neufundland) . . . . . . 375

2. Die Vereinigten Staaten von (Nord-) Amerika (Union) . . . . 388

B. Mexico und Mittelamerika (Zentralamerika und Westindien) . . 420

C. Südamerika . . . . . . . . . . . . . . . . . . . . 4 437

Allgemeines . . . . . . . . . . . . . . . . . . . 437

1. Die Andenländer. . . . . . . . . . . . . . . . . . . 439

2. Der ungefaltete Osten Südamerikas . . . . . . . . . . . . 455

VI. Die Nord- und Südpolarländer 474

Register . . . . . . . . . . . . . . . . . . . 480 